Vol. 5 (1996): 299-310.

\title{
Modelling growth and nitrogen balance of barley under ambient and future conditions
}

\author{
Jouko Kleemola' \\ Department of Plant Production, P.O. Box 27, FIN-00014 University of Helsinki, Finland \\ Tuomo Karvonen \\ Laboratory of Hydrology and Water Resources Engineering, \\ University of Technology, Espoo, Finland
}

\begin{abstract}
According to current scenarios, atmospheric $\mathrm{CO}_{2}$-concentration $\left(\left[\mathrm{CO}_{2}\right]\right)$ and average air temperature will rise in the future. The predicted longer growing season in Finland would imply that more productive cultivars and even new crop species could be grown. Moreover, higher $\left[\mathrm{CO}_{2}\right]$ is also likely to increase dry matter production of crops. This study analyzed the growth of spring barley (Hordeum vulgare $L$.) under ambient and suggested future conditions, and its response to $\mathrm{N}$ fertilization. Model simulations of soil temperature and of snow accumulation and melting were also studied. The calibration and validation results showed that the model performed well in simulating snow dynamics, soil temperature, the growth of barley, and the response of crop growth to $\mathrm{N}$ fertilization under present conditions. According to the simulation runs, if a cultivar was adapted to the length of the growing period, the increase in dry matter production was $23 \%$ in a low estimate scenario of climate change, and $56 \%$ in a high estimate scenario under a high level of nitrogen fertilization. The simulation study showed that the shoot dry weight increased by $43 \%$, on average, under high $\mathrm{N}$ fertilization (150-200 $\mathrm{kg} \mathrm{N} / \mathrm{ha})$, but by less $(20 \%)$ under a low level of $\mathrm{N}(25-50 \mathrm{~kg} \mathrm{~N} / \mathrm{ha})$ when the conditions under a central scenario for the year 2050 were compared with the present ones.
\end{abstract}

Key words: $\mathrm{CO}_{2}$ concentration, climate change, crop modelling, Hordeum vulgare $L$.

'Current address: Kemira Agro, Espoo Research Centre, P.O. Box 44, FIN-02271 Espoo, Finland

\section{Introduction}

According to current scenarios, atmospheric $\mathrm{CO}_{2}$-concentration $\left(\left[\mathrm{CO}_{2}\right]\right)$ and average air temperature will rise in the future. Carter (1992) stat- ed that an increase of $1.0^{\circ} \mathrm{C}$ in air temperature may result in a 10-day extension in the length of the growing season in Finland. The longer growing season will enable spring cereals to be sown earlier. This, in turn, would mean that more productive cultivars and even new crop species 


\section{Kleemola, J. \& Karvonen, T.: Modelling growth of barley}

could be grown (Carter 1992). Moreover, in addition to the increase in crop productivity caused by a longer growing period, higher $\left[\mathrm{CO}_{2}\right]$ is likely to increase net photosynthesis, and thus the dry matter production of crops, in the future (Kimball 1983, Cure and Acock 1986).

A research group in the Department of Plant Production at the University of Helsinki has been developing a crop model which can be used to estimate the effect of changes in air temperature and $\left[\mathrm{CO}_{2}\right]$ on the development and growth of spring barley (Hordeum vulgare L.). In addition, the model simulates moisture, $\mathrm{N}$ and temperature dynamics in soil, and snow accumulation and melting. After validating the model, using data collected under present conditions, it can be used to estimate the impacts of climate change on agricultural production. For example, the previous version of the model used in the present study has been applied over a $10 \times 10$ $\mathrm{km}$ grid across Finland in a study on climate change reported by Carter et al. (1996).

A recent study by Kleemola et al. (1995) showed that a previous version of the model was capable of simulating the growth of spring barley cultivated in heavy clay soil under ambient conditions. Their study also included test data collected in a greenhouse where the $\mathrm{CO}_{2}$ was enriched above the ambient level. The model performed satisfactorily with these data too. The same field data were used in the present study, in which the model was constructed differently from that used by Kleemola et al. (1995). In this study, the model simulations of soil temperature, the dynamics of snow cover, and the response of barley to $\mathrm{N}$ fertilization are compared with data collected under present conditions. Moreover, the simulated effect of increases in air temperature and $\left[\mathrm{CO}_{2}\right]$ on the growth of barley are also reported. The future conditions are those suggested in scenarios developed for the Finnish Research Programme on Climatic Change (SILMU) (Carter et al. 1995, Carter 1996). Simulations were conducted for three policy-oriented scenarios of SILMU representing low, central, and high levels of change in climate and $\left[\mathrm{CO}_{2}\right]$ by the year 2050 . The respective climate changes are: for annual precipitation $+1.5 \%$, $+6.0 \%$ and $+9.0 \%$, and for mean annual temperature $+0.6^{\circ} \mathrm{C},+2.4^{\circ} \mathrm{C}$ and $+3.6^{\circ} \mathrm{C}$ relative to the present-day. For details of seasonal changes, see Carter (1996). The corresponding $\left[\mathrm{CO}_{2}\right]$ scenarios are $456 \mathrm{ppm}, 523 \mathrm{ppm}$ and $555 \mathrm{ppm}$, compared to a present-day concentration assumed to be $350 \mathrm{ppm}$.

\section{The model}

\section{Crop growth}

The present crop model is based on the potato model described by Karvonen and Kleemola (1995) and the barley model described by Kleemola et al. (1995). The crop development stage $\left(D_{v s}\right)$ is driven by the average daily temperature, the base temperature, and by the temperature sum required to complete each phase (Kleemola 1991). $D_{v s}$ is 0.0 at emergence, 0.5 at anthesis, and 1.0 at maturity. The model calculates crop production based on latitude, Julian day, daily global radiation, precipitation, and mean air temperature. The original crop model was slightly modified: the method presented by Teittinen et al. (1994) was used to determine the partitioning of dry matter between shoot organs. At first, their model calculates the increase in shoot dry weight. Then, using the new shoot dry weight and the relative amount of each shoot organ, determined as a function of development stage, a new value for the dry weight of each plant organ is calculated. The partitioning of dry matter between roots and shoots, however, is calculated according to van Keulen and Seligman (1987). The computation of the maximum net photosynthetic capacity of a leaf $\left(\mathrm{P}_{\mathrm{m}}, \mathrm{kg} \mathrm{CO} / \mathrm{ha}\right.$ leaf $\left./ \mathrm{h}\right)$ was also modified. $\mathrm{P}_{\mathrm{m}}$ is computed as a function of $\left[\mathrm{CO}_{2}\right]$ inside the stomatal cavity $\left(\mathrm{C}_{\mathrm{i}}\right)$ :

$$
P_{m}=x_{1} * \ln \left(C_{i}\right)-x_{2}
$$

This relationship was fitted to data adapted from Kemppi (1992), and the following parameter values were obtained: $x_{1}=30.513$ and $\mathrm{x}_{2}=119.91 . \mathrm{C}_{\mathrm{i}}$ is determined as a function of at- 
Vol. 5 (1996): 299-310.

mospheric $\left[\mathrm{CO}_{2}\right]$ using a constant ratio of 0.6 $\left(\mathrm{C}_{\mathrm{i}} /\left[\mathrm{CO}_{2}\right]\right)$.

\section{Soil water}

Water movement in soil is modelled using a modification of the DRAINMOD -model (Skaggs 1978, Skaggs et al. 1991). The model calculates the depth of the ground water table and water movement in soil using a method based on soil water balance. The input variables of the system are precipitation and the capillary rise of water in the soil profile, and the output variables are potential and actual evapotranspiration $\left(\mathrm{ET}_{\mathrm{pot}}\right.$ and $\left.\mathrm{ET}_{\mathrm{act}}\right)$, deep seepage and water flowing via drainage pipes. The water submodel requires a soil water retention curve and the saturated hydraulic conductivity of the soil as an input, and calculates water movement between soil layers, the depth of the ground water level, drainage flow, and soil moisture content in each layer as output variables. The thickness of the layer used was $10 \mathrm{~cm}$ in all the soil models. The estimates for $\mathrm{ET}_{\text {pot }}$ and $\mathrm{ET}_{\text {act }}$ are used for computing the effect of water stress on photosynthesis.

\section{Soil nitrogen}

Mineralization and the application of fertilizers increase the amount of mineral $\mathrm{N}$ in soil and the uptake by plants, leaching, and denitrification decrease it in the present model. Soil processes involved in the $\mathrm{N}$ balance, i.e., mineralization, dissolution of fertilizers, nitrification and denitrification, are modelled using first order reaction kinetics, i.e., the reactions are linearly related to the amount of substrate. This approach is commonly used in modelling soil nitrogen dynamics (de Willigen 1991). The movement of water-soluble $\mathrm{N}$ through soil occurs both by molecular diffusion and by mass transport in the soil-water phase. In the current model, diffusion processes are neglected and only convective transport is considered. Convective transport is a function of the soil-water flux between two layers, calculated by the soil water submodel, and the mineral nitrogen concentration of these layers. An ordinary differential equation was formulated for each layer (Karvonen and Varis 1992).

\section{Soil temperature}

Soil temperature is calculated using the model described by Karvonen (1988). The present model, however, unlike the approach used by Karvonen (1988), calculates heat transfer separately from mass (water) transfer in soil. The soil temperature model determines the heat transfer in soil on the basis of thermal conductivity and the heat capacity of each soil layer. Moreover, a soil-specific relationship between unfrozen water content and negative soil temperature is needed to take into account the influence of latent heat during freezing/melting periods. The model outputs are soil temperature and the distribution of total water content into unfrozen and frozen fractions in each layer. Frost depth is derived from soil temperature, i.e. the depth where the soil temperature equals $0.0^{\circ} \mathrm{C}$.

\section{Snow dynamics}

The snow model was detailed by Karvonen (1988). He combined the models presented by Kuusisto (1984), and by Jansson and Halldin (1980). The model includes submodels for determining the form of precipitation (snow or water), the melting of snow driven by air temperature, depth and density of snow cover, and the amount of free water and ice in snow.

\section{Calculation of sowing day}

The sowing day was given as an input under present conditions, while under future warmer conditions, it can be expected that sowing would be earlier. Using data from Jokioinen (see below), the dependence of the sowing day on weather was analysed. It was observed that the sum of precipitation between the date when the five-day moving average of air temperature rises above $5^{\circ} \mathrm{C}\left(\mathrm{D}_{\mathrm{b}}\right.$, Julian day) and the sowing date explained $90 \%$ of the variation in sowing dates during a six-year period. Based on this information, we developed a simple model to de- 


\section{AGRICULTURAL AND FOOD SCIENCE IN FINLAND}

\section{Kleemola, J. \& Karvonen, T.: Modelling growth of barley}

termine the sowing day under future conditions. The model calculates an index, initialized at 0 when the moving average of air temperature rises above $5^{\circ} \mathrm{C}$, and reaching 1 at sowing. The index is increased by a parameter related to $D_{b}$ $\left(0.000523 * \mathrm{D}_{\mathrm{b}}\right)$, and decreased by a precipitation parameter $(\mathrm{P}, \mathrm{mm} / \mathrm{d})$, in case it is raining $(0.1517 * \mathrm{P})$.

\section{Calibration and validation of the model}

\section{Experimental data}

Two sets of data were employed in the calibration and validation of the model. The first set of data, comprising measurements of crop growth response to nitrogen fertilization, was collected at Viikki Experimental Farm, the University of Helsinki $\left(60^{\circ} 10^{\prime} \mathrm{N}, 25^{\circ} 00^{\prime} \mathrm{E}\right)$ during the period 1986-87. These experiments were detailed by Kiltilä (1988), and are only briefly outlined here. The meteorological data needed for running the crop model (daily global radiation, precipitation, and mean air temperature) were recorded $10 \mathrm{~km}$ from the farm at Kaisaniemi, a meteorological station of the Finnish Meteorological Institute (FMI). The soil type in the experiment was sandy and muddy clay in 1986, and sandy and silty muddy clay in 1987. Both soil types were rich in organic matter (6-12\% by weight). The spring barley cultivar, Agneta, was supplied with 10, 50,90 or $120 \mathrm{~kg} \mathrm{~N}, 40 \mathrm{~kg} \mathrm{P}$ and $62 \mathrm{~kg} \mathrm{~K} / \mathrm{ha}$ at sowing. Above ground crop dry weight $(\mathrm{kg} / \mathrm{ha})$ was recorded at the yellow ripeness stage (moisture content of grains about $35 \%$ ). For modelling purposes, the saturated soil conductivity values were assumed to be the same as those used for data from Jokioinen $\left(60^{\circ} 49^{\prime} \mathrm{N}, 2^{\circ} 30^{\prime} \mathrm{E}\right)$, adapted from Aura (1990). The water retention curve was adapted from Andersson and Wiklert (1972), according to the soil classification given by Kiltilä (1988).

The second set of data was used to analyse the performance of the model in simulating year to year variations in crop growth, snow dynamics and soil temperature. Furthermore, these data were also used as a baseline when conducting a sensitivity analysis for the model. The data were collected at the Agricultural Research Centre in Jokioinen, as a part of a joint Nordic project during the period 1982-1987 (Ilola et al. 1988). The meteorological data, as well as soil temperature and snow depth, were recorded at Jokioinen, a FMI site close to the experimental field. Soil temperature was measured once a week at the depths of 20,50 and $100 \mathrm{~cm}$. Snow depth was recorded daily, but five-day intervals were used in this study. The soil type in the experimental field was classified as heavy clay, with $63 \%$ of the topsoil particles $<0.002 \mathrm{~mm}$. In the model, the soil was treated as two layers: 1) 0 $30 \mathrm{~cm}$ as the top soil and 2) below $30 \mathrm{~cm}$ depth as the bottom soil. A spring barley cultivar, Pomo, was grown throughout the experiment. The crop was fertilized with $80-100 \mathrm{~kg} \mathrm{~N}, 35-$ $40 \mathrm{~kg} \mathrm{P}$, and 40-65 kg K/ha each year. Aboveground crop dry matter was monitored weekly, and these measurements were used in validating the crop model. The water retention curve was adapted from Andersson and Wiklert (1972), according to the physical characteristics of the soil reported by Ilola et al. (1988).

Model simulations were carried out on a yearly basis for the data of Viikki, as the experiments were conducted in different fields. For Jokioinen, the model was run continuously from 1 January 1982 until 31 December 1987, and the initial values for the soil state variables were given only once, at the beginning of the simulation period. The crop variables were initialized at sowing each year.

\section{Crop response to nitrogen fertilization}

The data collected at Viikki Experimental Farm in 1987 were used for calibrating the response of the crop to nitrogen fertilization, and the data from 1986 were used for validating the nitrogen response. The base temperatures used in determining the development rate of the crops were adapted from Saarikko et al. (1993). The tem- 


\section{AGRICULTURAL AND FOOD SCIENCE IN FINLAND}

Vol. 5 (1996): 299-310.

perature sum requirements of the crops for the periods between emergence and heading, and between heading and yellow ripeness were adjusted using the data from the year 1987. The parameter determining the lower limit of the range in which the leaf $\mathrm{N}$ content $\left(\mathrm{g} \mathrm{N} /\right.$ leaf $\left.\mathrm{m}^{2}\right)$ does not limit the photosynthesis was also calibrated using 1987 data. The values for the other parameters of the model were taken from Kleemola et al. (1995), and Kleemola et al. (1996), who also gave a description for those parameters. Figure 1a indicates that the calibration was successful, despite a small overestimation of the crop dry weight at the lowest $\mathrm{N}$ treatment. The weather conditions in the year 1986 were quite different from those of the year 1987: the average temperature was $14.8^{\circ} \mathrm{C}$ in May-July $\left(12.5^{\circ} \mathrm{C}\right.$ in 1987) and the total precipitation was $147 \mathrm{~mm}$ (170 mm in 1987). However, the model performed satisfactorily in 1986, too (Fig. 1b), though in contrast to 1987 , the crop dry weight was slightly underestimated at the lowest nitrogen level. Figure 1 also indicates that both the observed and simulated optimal nitrogen fertilization level, i.e. the nitrogen fertilization level at which additional nitrogen does not increase growth, was lower in 1986 than in 1987, presumably because of water deficiency.

\section{Crop growth}

The same set of parameters as in the nitrogen data above were used when running the model for the second set of data collected at Jokioinen, 1982-87. However, as the cultivar was different, the parameters determining the temperature sum requirements of the crop were changed. The values were taken from Saarikko et al. (1993). The model performed well compared to observations in simulating the shoot dry weight (DW) at Jokioinen. The coefficient of determination $\left(\mathrm{r}^{2}\right)$ for all the samples taken during the growing periods in $1982-87$ was 0.90 . The coefficient of variation was 8.5 and $8.6 \%$ for the measured and the simulated shoot DW at maturity, respectively. As an example, Fig. 2a shows the time-course of the measured and the simulated shoot dry weight for the year 1983, when the weather con-
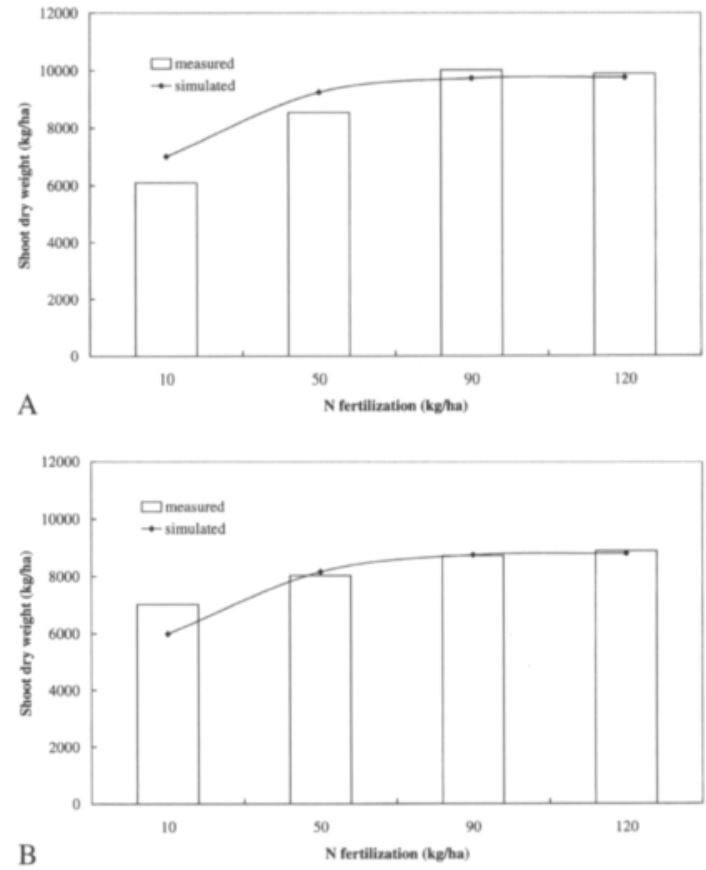

Fig. 1. The response of simulated and measured crop growth to $\mathrm{N}$ fertilization in (a) 1987 and (b) 1986. The model was calibrated using data from 1987.

ditions were close to the optimum for crop growth. Figure 2 b presents data for 1984 , when the soil moisture was in excess and was reported as restricting crop growth (Ilola et al. 1988). However, the simulated response of crop growth to this excess soil moisture was greater than the one observed. Figure $2 b$ shows that the simulation was erroneous during a two-week period after the day number 175; during the rest of the growing period the simulated growth rate was close to that observed.

\section{Soil temperature}

We compared the simulation results of the soil temperature model with the data of the years 1982-84, collected at Jokioinen. As the temperature was measured weekly the data comprised 156 observations at each depth. The model ac- 
Kleemola, J. \& Karvonen, T.: Modelling growth of barley
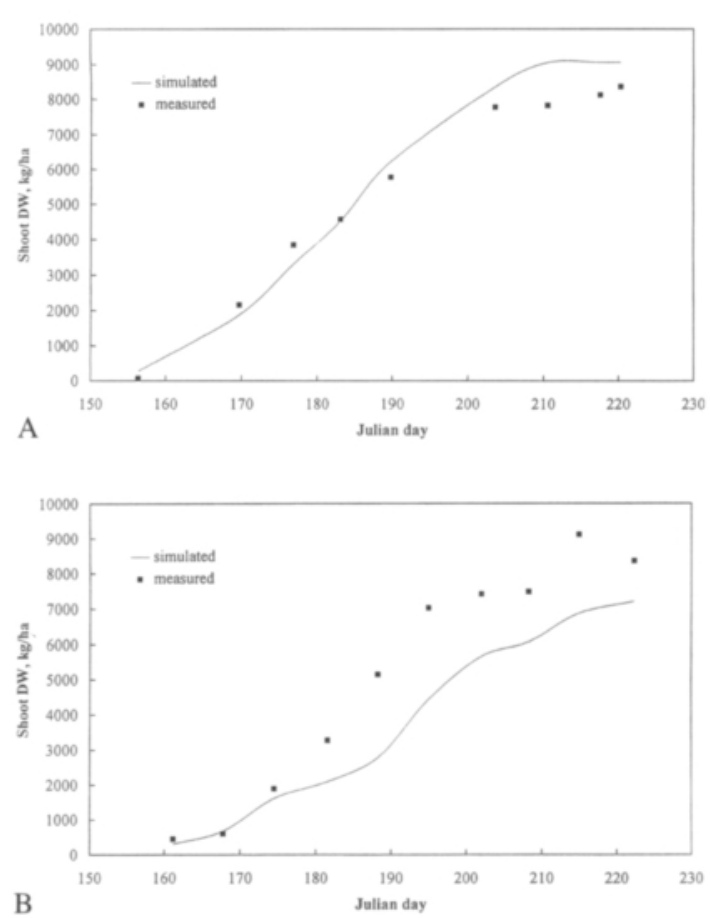

Fig. 2. The time-course of simulated and measured shoot dry weight at Jokioinen in (a) 1983 and (b) 1984.

counted for 95,96 and $97 \%$ of the variation between the measured and the simulated soil temperatures, pooled for all three years, at the depths of 20,50 and $100 \mathrm{~cm}$, respectively. At each depth, the variation in the simulated values was smaller than in the measured ones. The time-course of the soil temperature at the depth of $20 \mathrm{~cm}$ is shown in Fig. 3 for the years 1982 (a) and 1983 (b). The model performed satisfactorily throughout each year, except in the spring, when the simulated soil temperature rose more rapidly than the measured one in both years. Moreover, the model overestimated the soil temperature in winter 1983 . This may have been caused by the fact that the soil water model tends to overestimate the soil moisture content of the top soil layers. The simulated soil probably had more water to freeze than the actual soil, and for the same available energy proportionally less water froze than actually happened so that the simulated soil tem- perature remained higher than the measured one. Another reason for the overestimation may have been that the depth of the snow cover was small in 1983 (see later) and the model may have exaggerated the heat flux through the thin snow cover into the soil.

\section{Snow depth}

The appearance and disappearance of snow cover was modelled satisfactorily. The simulation of snow depth was not as good (Fig. 4). The model was able to explain $81 \%$ of the variation in the measured snow depth during the winters 198284 (pooled for all three years). The simulated values were generally slightly higher than those measured. An accurate estimation of the depth (and density) of snow is essential for simulating the soil temperature successfully in the winter and the spring. There exists a clear relation between the snow depth and the soil temperature during the winter (Figs 3,4): the thicker the snow cover the higher the soil temperature.

\section{Results}

\section{Sensitivity analysis}

The sensitivity of the model outputs to changes in variables suggested to be affected by climate change, were analysed. The sensitivity analysis was conducted in order to aid in making conclusions about the results given by the model for the weather conditions in 2050. The baseline weather used was the 1982-87 data from Jokioinen, and the nitrogen fertilization rate was assumed to be $200 \mathrm{~kg} / \mathrm{ha}$. Model runs were conducted for the low, central and high scenarios of SILMU. One variable (air temperature, precipitation and $\left.\left[\mathrm{CO}_{2}\right]\right)$ at a time was adjusted according to each scenario. The results of the sensitivity analysis are presented in Table 1 . Table 1 shows that the effect of $\mathrm{CO}_{2}$ on crop growth was bigger than that of the other variables according to the model. The year to year variation was slightly decreased when compared to ambient 
Vol. 5 (1996): 299-310.
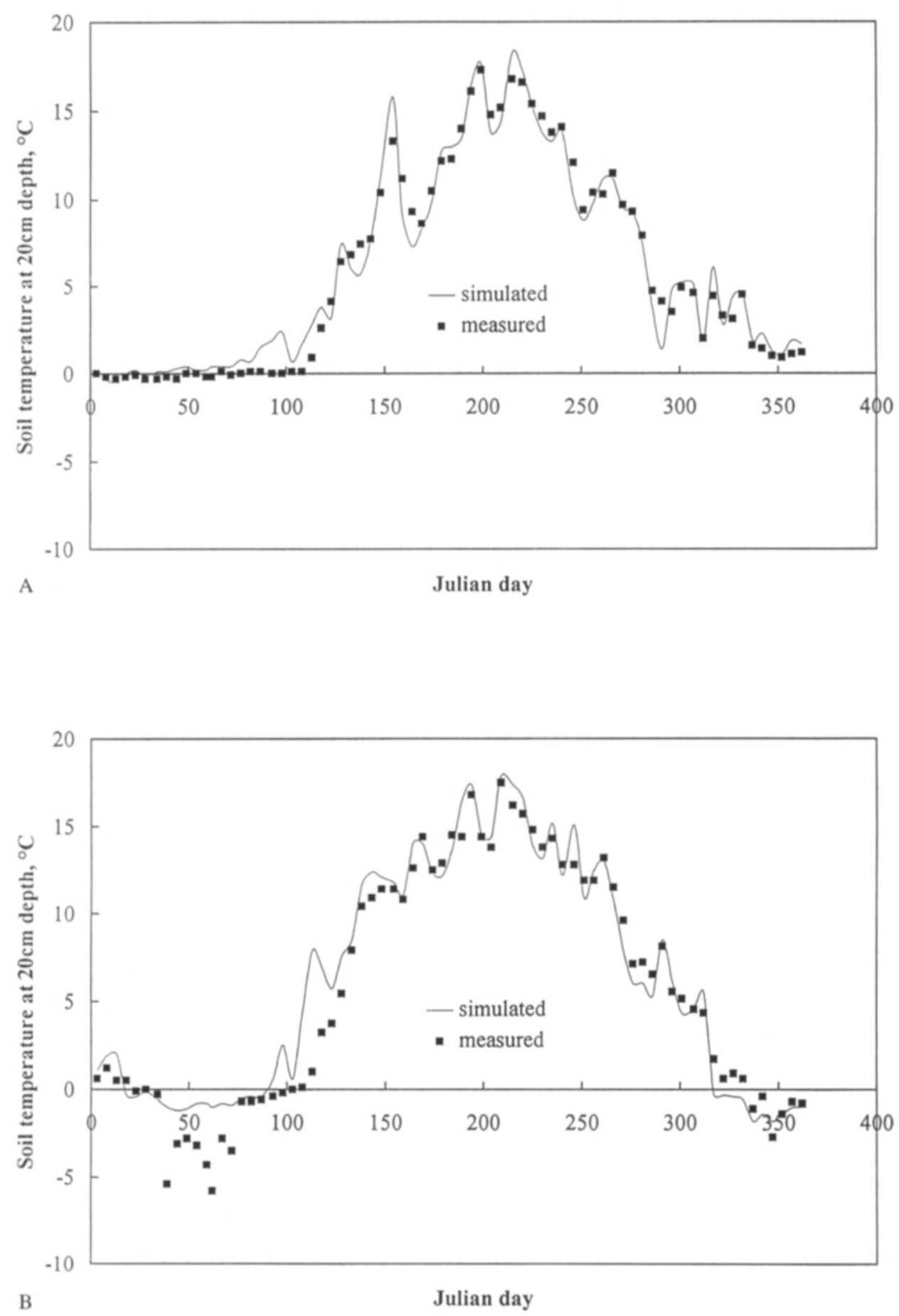

Fig. 3. The time-course of simulated and measured soil temperature at the depth of $20 \mathrm{~cm}$ in (a) 1982 and (b) 1983. 


\section{AGRICULTURAL AND FOOD SCIENCE IN FINLAND}

Kleemola, J. \& Karvonen, T.: Modelling growth of barley

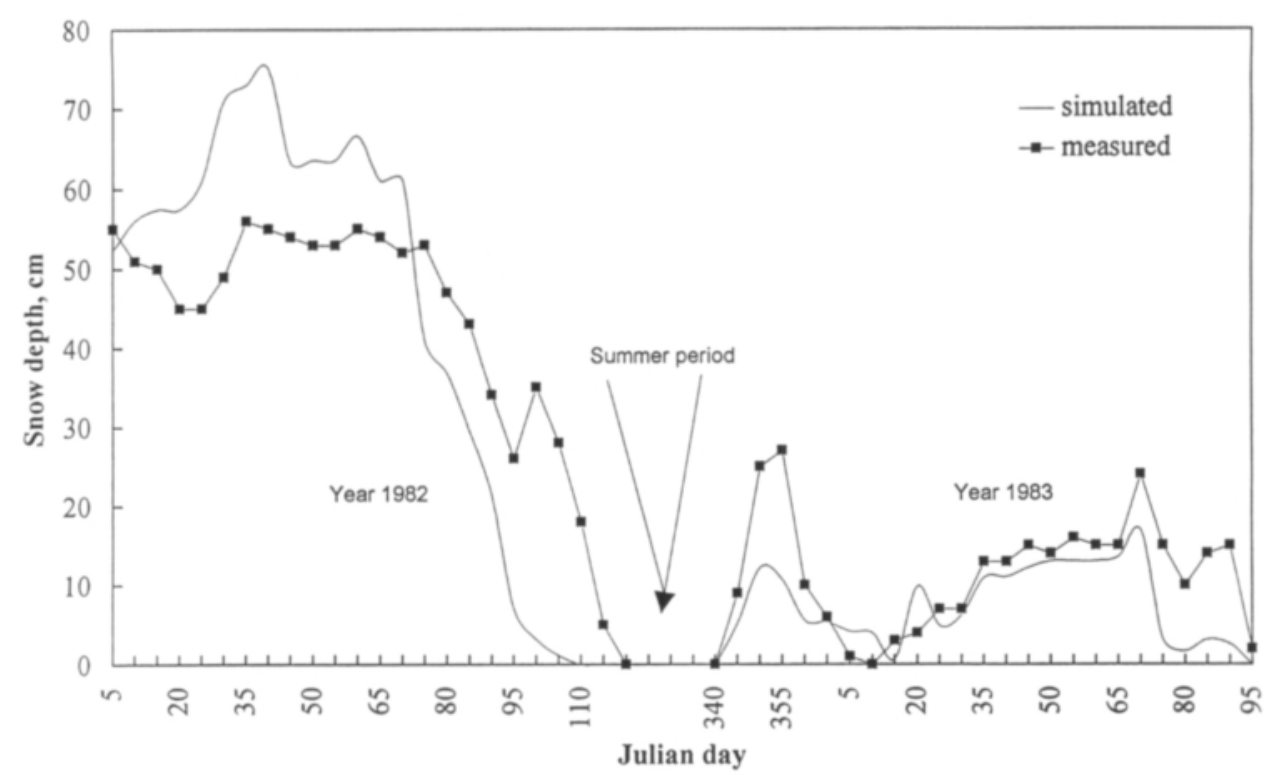

Fig. 4. The time-course of simulated and measured snow depth during the winters of 1982 and $1982-83$.

conditions. The increase in precipitation had little affect on crop growth. Neither was the variation between years affected. However, the increase in precipitation clearly increased the amount of drainage water in the autumn and the spring (results not shown). Higher air temperature decreased shoot dry weight and increased the variation between years. The decrease in shoot dry weight resulted, in part, from acceler-

Table 1. Sensitivity analysis of the model: the response of simulated shoot dry weight (relative to the present) of present-day barley cultivar to the changes in air temperature, precipitation and $\left[\mathrm{CO}_{2}\right]$. One weather variable was increased in time according to SILMU low, central and high scenario. Weather data collected at Jokioinen during the period 1982-87 was used a baseline. Coefficient of variation $(\mathrm{CV}, \%)$ between years shown in parenthes; $\mathrm{CV}$ was $9.20 \%$ for the baseline period.

\begin{tabular}{|c|c|c|c|}
\hline Weather variable & Low & $\begin{array}{c}\text { Scenario } \\
\text { Central }\end{array}$ & High \\
\hline Prec & $100(9.17)$ & $101(9.04)$ & $101(9.11)$ \\
\hline Temperature & $98(9.90)$ & $92.0(12.6)$ & $87.5(14.1)$ \\
\hline$\left[\mathrm{CO}_{2}\right]$ & $120(7.93)$ & $129(7.36)$ & $133(7.16)$ \\
\hline
\end{tabular}

ated development under higher temperatures and a consequent shortening in the length of the growing period. Higher temperatures also increased the potential evapotranspiration, leading to a decrease in shoot dry weight in dry years.

Crop growth responses under scenarios of climate change

A few test runs were made to determine the effect of the suggested changes in $\left[\mathrm{CO}_{2}\right]$, air temperature and precipitation on crop growth. The baseline weather used was the 1982-87 data from Jokioinen. Under the central scenario of SILMU for 2050, the simulation runs suggested that the average shoot DW of barley would increase by $23 \%$ if a present-day barley cultivar, such as Pomo was used and the $\mathrm{N}$ fertilization level was $100 \mathrm{~kg} /$ ha (Table 2). The interannual variability of the shoot DW increased slightly, in accordance with an increase in the variability of the length of the growing period. However, if the cultivar was changed to one requiring a higher temperature sum for maturing, the increase in shoot DW was $35 \%$ and the coefficient of variation decreased. 


\section{AGRICULTURAL AND FOOD SCIENCE IN FINLAND}

Vol. 5 (1996): 299-310.
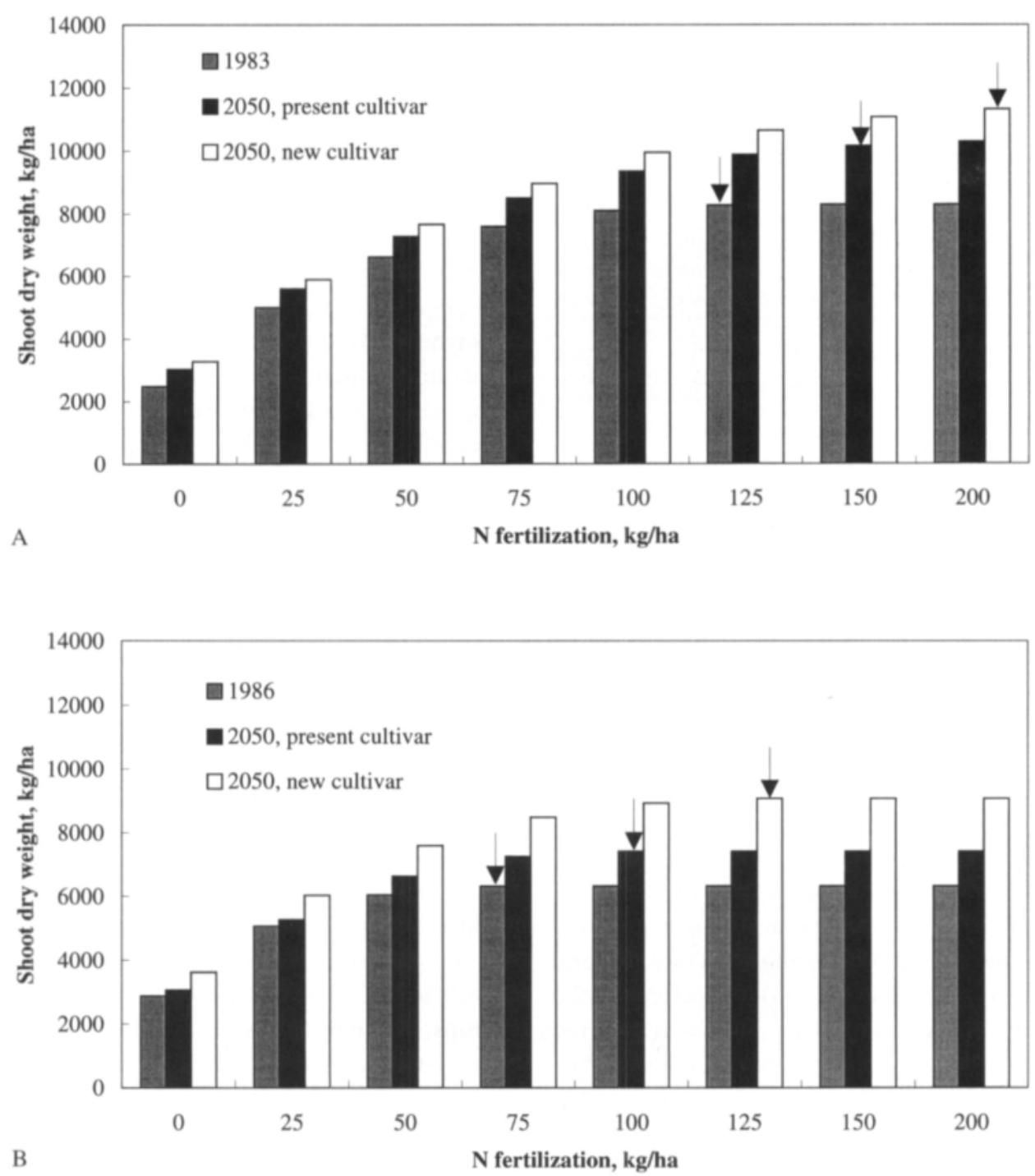

Fig. 5. The simulated response of crop growth to $\mathrm{N}$ fertilization under observed conditions, and under conditions adjusted according to the central scenario of SILMU with increased $\mathrm{CO}_{2}$-concentration and air temperature by 2050, for (a) a favourable year (1983) and (b) a dry year (1986). Arrows indicate the $\mathrm{N}$ fertilization level required for a maximum yield.

The model was also used to estimate the crop response under the low and high climate change scenarios of SILMU (Table 2). The "new" crop cultivar was assumed to be adapted to the changed conditions, so that the sowing day was assumed to change according to the climate, and the development rate was adjusted so that the harvest dates were close to those observed under ambient conditions. Again, the model suggested clear increases in crop growth: by $23 \%$ under the low scenario and by $56 \%$ under the high scenario of SILMU assuming a high $\mathrm{N}$ fertilization rate, $200 \mathrm{~kg} / \mathrm{ha}$ (Table 1).

Some simulation runs were also conducted 
Kleemola, J. \& Karvonen, T.: Modelling growth of barley

Table 2. Average simulated increase (\%) in shoot dry weight of a present-day and a new barley cultivar when shoot dry weight obtained under conditions in 2050 was compared to one obtained under present conditions. Weather data collected at Jokioinen during the period 1982-87 were used as the baseline.

\begin{tabular}{lcccc}
\hline & $\begin{array}{c}\text { central } \\
\text { scenario } \\
\text { N fertilization }\end{array}$ & & $\begin{array}{c}\text { low } \\
\text { present cv. }\end{array}$ & $\begin{array}{c}\text { high } \\
\text { scenario } \\
\text { new cv. }\end{array}$ \\
\hline $100 \mathrm{~kg} \mathrm{~N} / \mathrm{ha}$ & 23 & 35 & - & - \\
$200 \mathrm{~kg} \mathrm{~N} / \mathrm{ha}$ & 25 & 43 & 23 & 56 \\
\hline
\end{tabular}

in order to analyse the effect of climate change on the optimal rate of $\mathrm{N}$ fertilization. Figure 5 shows the simulated crop response when weather data from two different years were used as baseline conditions. The growing conditions were very favourable in 1983, whereas in 1986 they were much drier. According to the simulations, enhanced crop growth requires additional nitrogen. Under present-day conditions, when the growing conditions are good shoot DW continues to increase with increasing nitrogen fertilization up to a level of $125 \mathrm{~kg} \mathrm{~N} / \mathrm{ha}$ (Fig. 5a). However, if soil moisture deficiency restricts growth, the optimum $\mathrm{N}$ fertilization rate is found at much lower levels (Fig. 5b). The effect of the scenario changes in climate is to increase the level at which this "saturation effect" of nitrogen occurs, under both favourable and drought conditions. The effect is reinforced in simulations with an adapted cultivar (Figure 5).

\section{Discussion}

The model performed well at simulating various components of the soil-plant atmosphere system for which measurements were available for comparison. This indicates that the simulation results given in the present paper are credible for the kind of weather and soil types used in this research. However, more validation stud- ies are required since this is the first time the model has been applied in its present configuration. For example, experiments on only two soil types were considered, and measurements of crop responses under enriched $\left[\mathrm{CO}_{2}\right]$ were not used. Moreover, data on the soil $\mathrm{N}$ content and soil moisture were not available.

According to the simulation results climate change will clearly enhance crop growth under northern conditions. The increase in the dry matter production, as a result of a longer growing period and higher $\left[\mathrm{CO}_{2}\right]$, is not likely to be counteracted either by the increased development rate of crops, and the shortened grain filling period, or by the increased potential evapotranspiration inducing water deficiency conditions for crops. It was observed that the increase in yields is also dependent on the cropping methods employed. As shown in Table 1, the increase in temperature decreases shoot dry weight by decreasing the length of the growing period. This effect is more than counter balanced by the positive effect of the increase in $\left[\mathrm{CO}_{2}\right]$ (Table 2). A further increase in yields will be obtained, for example, if new cultivars, with a longer growing period are used. Moreover, the nutrient requirements of crops will also increase if the growth is enhanced.

The results of this study refer to spring-sown crops. Some of the aspects and trends may hold for winter crops, too. The higher $\left[\mathrm{CO}_{2}\right]$ will increase the photosynthesis of winter crops in Finland. However, the crop system for autumn-sown crops is more complex than for the spring-sown crops. It is likely that the frequency of warm periods in the winter time, during which the snow disappears, will increase under a changed climate, as indicated by our model (results not shown). This, in turn, may affect the susceptibility of crops to winter damage. In addition, the refreezing of the melted water can also cause damage. On the other hand, the total duration of snow cover will probably decrease, which will be beneficial for overwintering crops. The shorter the winter period, the smaller the storage of assimilates crops have to accumulate in the autumn to survive. Biochemical reactions require 
Vol. 5 (1996): 299-310.

some energy during the winter period too, and as assimilation is not possible in the winter due to low temperatures and probable snow cover, the plants have to accumulate some assimilates prior to overwintering. It is difficult to design field experiments for studying these problems, as the heating of field plots would be very difficult in the winter without disturbing other prevailing conditions. A partial solution would be to analyse the exisiting data on overwintering during warm winters under ambient conditions.

Acknowledgements. This study was financed by the Academy of Finland as a part of the Finnish Research Programme on Climatic Change (SILMU).

\section{References}

Andersson, S. \& Wiklert, P. 1972. Markfysikaliska undersökningar i odlad jord. XXIII. Om de vattenhállande egenskaperna hos svenska jordarter. (Water-holding properties of Swedish soils). Grundförbättring 25: 53-143. Aura, E. 1990. Salaojien toimivuus savimaassa (The function of drainage pipes in clay soils). Maatalouden tutkimukeskus, Tiedote 10/90. 93 p.

Carter, T. R. 1992. The greenhouse effect and Finnish agriculture. Maatilahallinnon aikakauskirja 1/1992: 31-57. - 1996. Developing scenarios of atmosphere, weather and climate for northern regions. Agricultural and Food Science in Finland 5: 235-249 (this issue).

-, Posch, M. \& Tuomenvirta, T. 1995. SILMUSCEN and CLIGEN, User's Guide. Publications of the Academy of Finland 5/95. Painatuskeskus Oy, Helsinki, Finland. 62 p.

-, Saarikko, R. A. \& Niemi, K. J. 1996. Assessing the risks and uncertainties of regional crop potential under a changing climate in Finland. Agricultural and Food Science in Finland 5: 329-350 (this issue).

Cure, J.D. \& Acock, B. 1986. Crop responses to carbon dioxide doubling: a literature survey. Agricultural and Forest Meteorology 38: 127-145.

Ilola, A., Elomaa, E. \& Pulli, S. 1988. Testing of a Danish growth model for barley, turnip rape, and timothy in Finnish conditions. Journal of Agricultural Science in Finland 60: 631-660.

Jansson, P.-E. \& Halldin, S. 1980. Soil water and heat model. Technical description. Technical Report 26, Swedish Coniferous Forest Project, Uppsala, Sweden. 81 p.

Karvonen, T. 1988. A model for predicting the effect of drainage on soil moisture, soil temperature and crop yield. Laborotory of Hydrology and Water Resources Engineering, Helsinki University of Technology. 215 p. Ph.D. thesis.

- \& Kleemola, J. 1995. Prediction of water and nitrogen limited crop production. In: Kabat, B. et al. (eds.). Modelling and parametrization of the soil-plant-atmosphere system: A comparison of potato growth models. Wageningen Pers, Wageningen, The Netherlands. p. 335-369. - \& Varis, E. 1992. Components of soil nitrogen balance. In: Karvonen, T. \& Varis, E. (eds.). Mathematical models in crop production. Department of Plant Production, University of Helsinki, Publication nr: 32. p. 161-176.

Kemppi, V. 1992. IImakehăn pitkăaikaisen korkean CO2 -pitoisuuden vaikutus vehnăn ja ohran yhteyttămiseen, kasvunopeuteen sekă kloroplastien hienorakenteeseen. (The effect of long-term $\mathrm{CO}_{2}$ enrichment on the rate of photosynthesis and growth, and fine-structure of chlorophyll of wheat (Triticum aestivum L.) and barley (Hordeum vulgare)). Department of Plant Production, University of Helsinki. 77 p. M.Sc. thesis.

Keulen, H. van \& Seligman, N.G. 1987. Simulation of water use, nitrogen nutrition and growth of a spring wheat crop. Pudoc, Wageningen, The Netherlands. 310p.

Kiltilä, K. 1988. Ohran typpilannoituksen vaikutus aluskasvien kasvuun. (The effect of nitrogen fertilization of barley on growth of under sown crops). Department of Plant Production, University of Helsinki. 105 p. M.Sc. thesis.

Kimball, B.A. 1983. Carbon dioxide and agricultural yield: An assemblage and analysis of 430 prior observations. Agronomy Journal 75: 779-788.

Kleemola, J. 1991. Effect of temperature on phasic developement of spring wheat in northern conditions. Acta Agriculturae Scandinavica 41: 275-283.

-, Pehu, E., Peltonen-Sainio, P. \& Karvonen, T. 1995. Modelling the impact of climatic change on growth of spring barley in Finland. Journal of Biogeography 22: 581-590.

-, Teittinen, M. \& Karvonen, T. 1996. Modelling crop growth and biomass partitioning to shoots and roots in relation to nitrogen and water availability, using a maximisation principle. I. Model description and validation. Plant and Soil (in press).

Kuusisto, E. 1984. Snow accumulation and snowmelt in Finland. Publications of the Water Research Institute 55, Helsinki, Finland. 149 p.

Saarikko, R.A., Carter, T.R. \& Kleemola, J. 1993. Determining temperature and photoperiod effects on the phenological development of spring cereals under northern conditions. In: Wilson, D. et al. (eds). Crop Adaptation to Cool, Wet Climates, COST Workshop, Aberystwyth, UK, 23-24 March 1993. p. 165-174. 
Kleemola, J. \& Karvonen, T.: Modelling growth of barley

Skaggs, R.W. 1978. A water management model for shallow water table soils. North Carolina Water Resources Institute, Report No. 134. North Carolina State University, Raleigh, NC, USA. 178 p.

-, Karvonen, T \& Kandil, H. 1991. Predicting Soil water fluxes in drained lands. An ASAE (American Society of Agricultural Engineers) meeting presentation, Paper No. 912090. 23 p.
Teittinen, M., Karvonen, T. \& Peltonen J. 1994. A dynamic model for water and nitrogen limited growth in spring wheat to predict yield and quality. Journal of Agronomy and Crop Science 172: 90-103.

Willigen, P. de 1991. Nitrogen turnover in the soil-crop system; comparison of fourteen simulation models. Fertilizer Research 27: 141-149.

\title{
SELOSTUS
}

\section{Ohran kasvun ja typpidynamiikan mallintaminen nykyisissä ja tulevaisuuden olosuhteissa}

\author{
Jouko Kleemola ja Tuomo Karvonen \\ Helsingin yliopisto ja Teknillinen korkeakoulu
}

Tutkimuksessa analysoitiin ohran kasvua ja typpilannoituksen vaikutusta siihen kokeellisten aineistojen ja matemaattisen mallin avulla. Mallin toimivuutta testattiin nykyisissä oloissa kerätyillä aineistoilla, ja mallia käytettiin ennustamaan ilmastonmuutoksen vaikutusta ohran kasvuun. Samalla analysoitiin mallin kykyä simuloida maan lämpötilaa sekä lumen kertymistä ja sulamista. Kalibrointi- ja testaustulokset osoittivat, että käytetty malli simuloi hyvin ohran kasvua ja typpilannoituksen vaikutusta siihen sekä maan lämpötilaa ja lumen kertymistä ja sulamista nykyisissä oloissa. Ohran fytomassa nykytasoon verrattuna oli hitaan ilmastonmuutoksen oloissa $23 \%$ suu- rempi ja nopean ilmastonmuutoksen oloissa $56 \%$ suurempi, jos viljelijän oletettiin vaihtavan lajiketta kasvukauden pituuden mukaan ja käyttävän korkeaa typpilannoitustasoa. Keskinopean muutosennusteen mukaan ohran fytomassa lisääntyi korkeaa typpilannoitustasoa ( $200 \mathrm{~kg} \mathrm{~N} / \mathrm{ha})$ käytettäessä suhteellisesti enemmän kuin alhaista typpilannoitustasoa (100 kg N/ha) käytettäessä. Mallin antamien tulosten perusteella ohran kasvun lisääntymiseen vaikuttaa eniten kohoava hiilidioksidipitoisuus. Lämpötilan kohoaminen sen sijaan alentaa jonkin verran tuotantopotentiaalia, jos viljelyyn ei oteta uusia lajikkeita, jotka vaativat suuremman lämpösumman tuleentumiseensa. 